\title{
PENINGKATAN KEMAMPUAN MENULIS CERPEN MENGGUNAKAN MODEL PEMBELAJARAN PEDAGOGI GENRE, SAINTIFIK, DAN CLIL (CONTENT AND LANGUAGE INTEGRATED LEARNING) PADA SISWA KELAS XI SMAN 2 KOTA BENGKULU
}

\author{
Didi Yulistio dan Anita Fhitri \\ Program Studi S-2 Pendidikan Bahasa Indonesia \\ Pascasarjana FKIP Universitas Bengkulu \\ didi yulistio@yahoo.com
}

\begin{abstract}
Abstrak
Tujuan penelitian ini untuk mengetahui peningkatan kemampuan menulis cerita pendek menggunakan model pembelajaran Pedagogi Genre, Saintifik, dan CLIL (Content and Language Integrated Learning) pada Siswa Kelas XI-C SMAN 2 Kota Bengkulu. Ruang lingkup penelitian ini mencakup aspek (1) kesesuaian isi dengan tema, (2) struktur teks cerpen, (3) pilihan Kata (diksi), (4) penggunaan kalimat (gaya bahasa cerpen), dan (5) mekanik (ejaan dan tulisan tangan). Penelitian ini menggunakan metode penelitian deskriptif-kuantitatif dan model PTK (Penelitian Tindakan Kelas) yang terdiri atas 4 tahapan, yakni tahap perencanaan, pelaksanaan tindakan, pengamatan, dan refleksi. Sumber data penelitian siswa kelas XI-C SMAN 2 Kota Bengkulu sebanyak 28 orang dan data penelitian ini berupa teks cerpen. Pengumpulan data menggunakan petunjuk tes menulis cerpen dengan tema ditentukan dan lembar pengamatan aktivitas siswa. Analisis data menggunakan perhitungan rata-rata dan analisis akhir secara kualitatif. Hasil penelitian menunjukkan bahwa terjadi peningkatan kemampuan menulis Cerpen melalui model pembelajaran Pedagogi Genre, Saintifik, dan CLIL pada siswa kelas XI IPA-C SMAN 2 Kota Bengkulu. Hal ini terbukti dari hasil pembelajaran pada siklus I diperoleh rerata sebesar 70,21 dengan kategori baik dan meningkat pada hasil pembelajaran siklus II dengan rerata sebesar 80,14 dengan kategori sangat baik. Aktivitas siswa mencakup aspek disiplin, bertanggung jawab, kerjasama dan mandiri dengan kategori cukup aktif pada siklus I meningkat menjadi sangat aktif pada siklus II dalam materi pembelajaran mendeskripsikan struktur teks, nilai-nilai kehidupan, dan struktur pembangun cerpen.
\end{abstract}

Kata kunci: Kemampuan, menulis, cerpen, saintifik, pedagogi.

\begin{abstract}
The purpose of this study was to determine the improvement in the ability to write short stories using the Genre, Scientific, and CLIL (Content and Language Integrated Learning) learning models in Class XI-C Students of SMAN 2 Kota Bengkulu. The scope of this study includes aspects (1) conformity of content with themes, (2) structure of short story texts, (3) choice of words (diction), (4) use of sentences (short story style), and (5) mechanics (spelling and writing hand). This research uses descriptivequantitative research methods and PTK (Classroom Action Research) models which consist of 4 stages, namely the planning, action, observation, and reflection stages.
\end{abstract}


Sources of research data for class XI-C students of SMAN 2 Bengkulu City were 28 people and the data of this study were short story texts. Data collection uses test instructions to write short stories with specified themes and student activity observation sheets. Data analysis uses average calculations and final analysis qualitatively. The results showed that there was an increase in short story writing skills through the Genre, Scientific, and CLIL Pedagogy learning model for students of class XI Science-C of SMAN 2 in Bengkulu City. This is evident from the learning results in the first cycle obtained an average of 70.21 with good categories and increased in the learning outcomes of the second cycle with an average of 80.14 with a very good category. Student activities include aspects of discipline, responsibility, cooperation and independence with the category active enough in the first cycle to increase to be very active in the second cycle in the learning material describing the structure of the text, life values, and structure of short story builders.

Keywords: Ability, writing, short story, scientific, pedagogy.

\section{PENDAHULUAN}

Keberhasilan proses pembelajaran bahasa Indonesia di sekolah tidak saja tampak pada pencapaian keberhasilan siswanya tetapi juga ditentukan oleh kualitas guru yang mengajar di kelas. Pembelajaran bahasa Indonesia yang dikelola oleh guru bahasa Indonesia perlu berkualitas. Pembelajaran yang berkualitas tentu akan dapat dicapai ketika pembelajaran dikelola oleh guru bahasa Indonesia yang juga berkualitas. Kualifikasi guru bahasa Indonesia yang demikian tentu bermuara dari proses pendidikan yang dikelola Lembaga Pendidikan Tenaga Kependidikan (LPTK) termasuk dalam hal ini yakni FKIP Universitas Bengkulu sebagai pencetak calon guru. LPTK yang berkualitas tentu perlu diwujudkan dalam rangka mencetak pendidik berkompetensi pendidik sesuai tuntutan UU nomor 14 tahun 2005 tentang profesionalisme guru. Menurut undang-undang ini bahwa guru adalah pendidik profesional yang memiliki kompetensi (pedagogik, akademik, kepribadian, dan sosial). LPTK sebagai pencetak guru berkualitas disamping harus mewujudkan undang-undang tersebut juga berperan dalam menularkan kompetensi mengajar dengan model pembelajaran terbarukan kepada para pendidik di sekolah-sekolah. Tugas ini dilakukan pendidikan (dosen) di LPTK melalui kegiatan berkolaborasi dengan para pendidik di sekolah dalam mencapai tujuan pembelajaran pada tingkatan pendidikan tertentu. Praktik kegiatan ini dapat terlaksana salah satunya melalui pelaksanaan hibah Penugasan Dosen Ke Sekolah (PDS) LPTK dalam hal ini FKIP Universitas Bengkulu dalam misi diantaranya peningkatan proses dan hasil pembelajaran bahasa Indonesia siswa sekolah menengah atas.

Pembelajaran bahasa Indonesia kurikulum 2013 berbasis teks. Artinya, kegiatan pembelajaran mengacu pada penguasaan teks dengan tuntutan capaiannya, yakni kemampuan menulis teks sesuai jenisnya, seperti menulis teks cerpen. Pembelajaran berbasis teks ini dimaksudkan untuk mencapai kemampuan tinggi dalam penguasaan penggunaan struktur bahasa. Hal ini mengingat tingkat berpikir (literasi) siswa kita secara nasional, sesuai pencapaian level PISA bahasa tahun 2012 rata-rata hanya berada pada level 3 
sementara negara lain di Asia Tenggara sudah di atasnya (lihat hasil PISA 2009; 2012). Disamping itu, hasil capaian siswa yang belum membanggakan pada UN bahasa Indonesia berbasis KTSP dan dan Kurikulum 2013 (tahun 2017) serta hasil studi TIMMS, bahwa sebagian besar siswa Indonesia hanya mampu menjawab persoalan level menengah (sebanyak 95\%) sedangkan kemampuan siswa dalam menjawab soal yang memerlukan pemikiran (bernalar tinggi) masih belum memadai (hanya sekitar 5\%) (Kemdikbud, 2013:2). Oleh karena itu, tingkat literasi anak harus dilakukan pembinaan melalui budaya menulis, khususnya mengembangkan hal apa yang dilihat, didengar, dan dipikirkan sehingga memungkinkan memunculkan ide-ide kritiskreatif dalam bentuk literasi siswa yang lebih tinggi.

Kemampuan literasi (berpikir) siswa yang rendah tidak dapat dipungkiri sebagai dampak dari model pembelajaran bahasa Indonesia yang pilih dan diterapkan guru dalam proses pembelajaran. Oleh karena itu, pengembangan kemahiran berbahasa Indonesia melalui kemampuan menulis teks perlu dilakukan. Pengembangan kemampuan menulis berbasis teks adalah salah satu upaya membina dan mengembangkan pola berpikir siswa secara cepat, runtut, kritis, dan kreatif. Pada tingkat ini, siswa telah dituntut untuk menulis kalimat dengan gagasan sederhana dalam urutan yang jelas dan menggunakan kata-kata sendiri. Selanjutnya, pada tingkat sekolah menengah siswa dituntut mengembangkan tulisan dalam wujud teks berdasarkan rambu-rambu yang lebih lengkap seperti struktur teks dan pengembangan topik selain pemilihan kata dan penggunaan kalimat serta gaya bahasanya. Selain itu, sesuai standar kompetensi lulusan bidang studi bahasa Indonesia, bahwa orientasi menulis berkenaan dengan menulis efektif berbagai jenis teks dalam berbagai konteks dan tujuan untuk mencapai pembelajaran komunikatif (Bachman, 1990:85). Pembelajaran kemampuan menulis harus didasarkan pada penguasaan atau pemilikan siswa terhadap kaidah kebahasaan yang memadai dan kepekaan kontekstual yang tinggi. Sebab, menulis yang sederhana sekalipun tidak mungkin dapat terwujud tanpa pengetahuan tentang kaidah bahasa yang juga sederhana dan wawasan lingkungan cerita yang baik. Namun, kenyataan menunjukkan, hasil pembelajaran keterampilan menulis siswa masih jauh dari harapan. Masih banyak siswa yang kurang mampu menuangkan gagasan ke dalam tulisan secara baik, mengembangkan tema menjadi naskah dan isi tulisan yang runtut walaupun mereka telah mengikuti pelajaran bahasa Indonesia sejak sekolah dasar.

Hasil pengamatan terhadap
pelaksanaan pembelajaran bahasa Indonesia, bahwa berbagai upaya melatih siswa untuk menulis selama ini lebih banyak dilakukan setelah penjelasan tentang menulis berakhir. Akibatnya, pembelajaran menulis menjadi sebuah penjelasan teori yang panjang dan praktik menulis menjadi jarang dilakukan atau jika dilakukan menjadi tugas/pekerjaan rumah yang belum tentu mendapatkan bimbingan intensif dalam mewujudkan tulisan. Dampak pembelajaran menulis yang dikerjakan di rumah, membuat hasil pembelajaran menjadi kurang efektif dan tidak bermakna bagi siswa karena proses penuangan ide ke dalam teks tidak secara langsung dialami siswa. Sebagai bagian dari proses pembelajaran yang dikelola guru melalui "membangun konteks dan menelaah model" yang mestinya akan memperjelas dalam menulis namun karena hasil menulis tidak dikoreksi bersama sebagai upaya "mengontruksi teks secara 
bersama dan mengontruksi teks secara mandiri" karena pembelajaran keesokan harinya sudah harus melanjutkan materi berikutnya.

Kegiatan menulis memang bukan hal yang mudah bagi siswa di sekolah. Menurut beberapa guru, kesulitan utama terletak pada kegiatan menuangkan ide pokok atau gagasan ke dalam rangkaian kalimat yang runtut sehingga berwujud tulisan dan mudah dibaca. Tulisan siswa dimungkinkan kurang berkembang dengan baik, karenal ketika mulai menulis, apa yang sudah dipikirkan mengalami kebuntuan. Informasi yang diberikan guru bahwa kecenderungan siswa kurang mampu mengekspresikan gagasan dan keruntutan dalam berpikirnya. Kaitannya dengan implementasi kurikulum 2013, bahwa hambatan muncul kembali ketika mulai menulis berbagai jenis teks dan hal ini pun dialami oleh beberapa guru yang tampak belum siap mengekspresikan proses pembelajaran menulis teks secara terampil dan profesional. Untuk terampil menulis diperlukan latihan menulis secara rutin dan memperhatikan komponen dalam mewujudkan produk kemampuan menulis teks cerpen. Penguasaan komponen menulis, seperti isi (kesesuaian judul dengan isi), struktur teks, pilihan kata, penggunaan kalimat efektif dan gaya bahasa serta mekanik belum sepenuhnya diwujudkan. Menulis teks cerita (cerpen) merupakan bagian dari tuntutan keterampilan di sekolah menengah (Wiratno, 2014). Oleh karena itu, pemilikan kemahiran dalam menulis teks ini perlu diupayakan secara baik oleh guru bahasa Indonesia, khususnya dalam membelajarkan menulis siswa.

Kemampuan menulis merupakan kecakapan seseorang dalam berbahasa yang bersifat produktif karena menghasilkan produk, yakni tulisan. Murray dan Moore (2009:31) menyatakan bahwa kemampuan menulis sebagai proses kompleks dan kreatif seseorang dalam memproduk tulisan dari rangkaian kata menjadi kalimat dan paragraf menggunakan bahasa tulis. Kemampuan menulis merupakan kecakapan seseorang dalam merangkai bahasa dan keruntutan pikiran dalam tulisan sehingga dapat dikomunikasikan kepada pembaca secara berhasil. Hal ini sebagaimana Rivers (dalam Hadley, 1993: 290-292) mengemukakan bahwa kemampuan menulis merupakan kecakapan seseorang dalam praktik menulis secara alamiah dengan memanfaatkan konteks nyata. Definisi secara khusus, bahwa kemampuan menulis melibatkan dua hal yakni kemampuan menerima dan menggunakan. Kemampuan menggunakan berkaitan dengan aktivitas yang menekankan pada penggunaan kode bahasa untuk tujuan mengkomunikasikan gagasan, ide-ide dalam wujud tulisan. Byrne (dalam Yulistio, 2012: 25) menyatakan bahwa keterampilan menulis adalah suatu hasil usaha seseorang dalam mewujudkan dan kolektivitas pengetahuan kebahasaan dan pengolahan gagasan melalui pikiran yang direfleksikan melalui wujud tulisan sehingga dapat dikomunikasikan kepada pembaca secara berhasil. Dengan demikian, dapat dikatakan bahwa kemampuan menulis adalah kecakapan penulis (siswa) dalam menyampaikan gagasan, ide-ide atau pesan sebagai akumulasi pikiran dan pengalaman dengan menggunakan rangkaian lambang bahasa ke dalam wujud tulisan.

Agar seseorang terampil dalam menulis maka perlu berlatih secara intensif, gigih, dan tekun dalam mewujudkan produk tulisan yang baik. Ideris (2013:4-24) menegaskan bahwa gar kemampuan menulis menjadi kegiatan yang menarik dan menyenangkan maka seseorang harus mampu mengembangkan pola berpikir dalam tulisannya. Dalam membiasakan diri menulis perlu berlatih secara rutin. MaCrimmon (1984:10-11) menjelaskan tahap-tahap menulis, yang meliputi menyusun perencanaan, membuat draf 
tulisan dan pengembangannya serta melakukan revisi produk tulisan agar lebih sempurna. Richards dan Renandya (2002:316-319) menambahkan tiga tahap eksternal dalam proses menulis sebagai aktivitas kelas yang dilakukan oleh guru, yakni responding (sharing), evaluating, dan post-writing. Berdasarkan beberapa pendapat di atas dapat dideskripsikan bahwa tahapan menulis terdiri dari perencanaan (pre-writing), pembuatan draf, revisi, editing, review, evaluasi, dan tulisan lengkap (post-writing).

Cerpen merupakan salah satu bentuk karya sastra. Zainurrahman (2011:37) mengemukakan cerpen, yakni sebuah teks narasi yang bersifat fiksi dan menceritakan kejadian dan tikaian (konflik), serta menamkan nilai moral dan menghibur. Edgar Allan Poe (dalam Abrams, 1999: 286287) menambahkan bahwa cerpen memiliki sifat "pendek", yakni selesai dibaca dalam sekali duduk, kira- kira berkisar antara setengah jam sampai dua jam dan dibatasi oleh kekhasan tertentu dan memiliki efek tunggal. Berdasarkan pendapat ahli di atas dapat dikemukakan bahwa cerpen adalah teks naratif pendek fiktif dengan alur tunggal sederhana yang menceritakan sebuah kejadian dengan tujuan menghibur atau menanamkan nilai moral. Garry (2011:44) dan Margaret Lucke (1999:4-5) sepakat bahwa sebuah cerpen yang baik biasanya harus memiliki unsur pembangun, yakni tema, alur/plot, perwatakan, latar/setting, sudut pandang (point of view), dan gaya penulisan. Dalam kaitannya dengan kemampuan menilis, bahwa kemampuan menulis cerpen adalah suatu kecakapan atau kesanggupan seseorang untuk mengungkapkan ide, perasaan, dan pikiran melalui bentuk tulisan narasi fiksi pendek (cerpen) yang bertujuan menghibur dan penyampaian pesan moral. Dalam proses pembelajaran menulis cerpen, siswa dapat belajar menuliskan pengalaman hidupnya yang menarik dan berkesan untuk dinarasikan dan dibagikan kepada orang lain dalam bentuk tuisan cerpen. Melalui menulis cerpen bermanfaat dalam mengembangkan ide dan pengalamannya serta dapat sebagai inspirasi orang lain ketika membacanya. Melalui cerpen siswa dapat menyampaikan makna kehidupan melalui penanaman nilai-nilai moral kehidupan.

Pembelajaran menulis cerpen saat ini belum mampu membangun kreativitas siswa untuk secara rutin menulis sebagai keterampilan berkarya. Pembelajaran menulis cerpen masih sebatas mempelajari teori menulis cerpen dan belum mengakrabkan siswa untuk berkarya sastra secara langsung. Karena sifat pembelajarannya yang teoretis, para siswa mengalami kesulitan dalam menuliskan ide, gagasan cerita pendek dengan baik dan sistematis. Pada pembelajaran menulis cerpen, siswa belum diarahkan untuk berpikir kritis, kreatif, dan sistematis dalam mengembangkan gagasan cerita menjadi bentuk tulisan cerpen. Hal ini terjadi karena pendekatan pembelajaran yang digunakan masih berpusat pada guru (teacher centered) dengan pembelajaran masih berfocus pada pemberian pengetahuan tentang cerpen. Pembelajaran bersifat satu arah dan menyebabkan siswa cepat bosan serta kurang kreatif. Akibatnya, pembelajaran menulis cerita pendek dirasa kurang menarik. Pembelajaran menulis cerpen ini biasanya diawali dengan guru memberikan tema khusus. Pada saat memilih tema menulis cerpen, siswa seolah-olah menjadi dibatasi oleh pemikiran guru. Hal tersebut menyebabkan siswa menjadi kesulitan menuangkan ide, pikirannya ke dalam tulisan cerpen. Disamping itu, guru kurang memperhatikan kebutuhan siswa dalam pembelajaran menulis cerpen, khususnya dalam menilai tulisan. Penilaian tulisan siswa hanya dilihat 
dari hasil akhir tulisan saja. Oleh karena itu, guru perlu memberikan langkah-langkah dalam menuliskan pengalamannya dalam bentuk tulisan cerpen dengan menjelaskan aspek dasar menilai cerpen agar menjadi pedoman dalam menulis cerpen seperti memperhatikan isi, struktur teks cerpen, pilihan kata, penggunaan gaya bahasa, dan aspek mekanik.

Disisi lain, pembelajaran menulis cerpen akan berhasil jika dilakukan dengan menggunakan

langkah-langkah pembelajaran yang baik dan mudah diikuti siswa. Dalam hal ini guru perlu memilih pendekatan atau metode dan model pembelajaran yang juga relevan dengan pembelajaran menulis cerpen. Dalam kurikulum 2013 pembelajaran menulis cerpen dapat dilaksanakan dengan menggunakan model khusus dalam pembelajaran bahasa Indonesia, yang menggabungkan tiga pendekatan, yakni pedagogi genre, saintifik dan CLIL (Content and Language Integrated Learning). Model ini bertujuan untuk mencapai kompetensi berbahasa Indonesia siswa secara optimal. Model pembelajaran ini dapat mengembangkan konsep Pedagogical Content Knowledge, yaitu model yang memadukan antara pemahaman isi materi pembelajaran (content knowledge) dan pemahaman cara mendidik (pedagogical knowledge) yang berbaur menjadi satu. Alur utama model pedagogi genre dilakukan melalui langkah-langkah 4M (Membangun konteks, Menelaah Model, Mengonstruksi Terbimbing, dan Mengonstruksi Mandiri). Kegiatan mendapatkan pengetahuan (KI-3) dapat dilakukan melalui pembelajaran dengan pendekatan berbasis keilmuan (saintifik) berupa kegiatan mengamati, menanya, mengumpulkan informasi, menalar, dan mengomunikasikan. Pengembangan keterampilan (KI-4) dilanjutkan dengan langkah mengonstruksi terbimbing dan mengonstruksi mandiri. Coyle (2008) mengemukakan bahwa CLIL merupakan suatu pendekatan yang sangat tepat untuk memahami materi pelajaran yang diajarkan sekaligus untuk memperdalam bahasa yang digunakan dalam pembelajaran. Bahasa tidak hanya sebagai media instruksional dalam pembelajaran tetapi juga sebagai tujuan dari pembelajaran tersebut (Setyaningrum, 2010). Melalui pendekatan CLIL digunakan untuk memperkaya pembelajaran dengan prinsip (a) isi teks berupa model atau tugas bermuatan karakter dan pengembangan wawasan serta kepedulian sebagai warganegara serta sebagai warga dunia, (b) unsur kebahasaan (komunikasi) menjadi unsur penting untuk menyatakan berbagai tujuan berbahasa dalam kehidupan, (c) setiap jenis teks memiliki struktur berpikir (kognisi) yang berbeda-beda yang harus disadari agar komunikasi lebih efektif; dan (d) budaya berbahasa (berkomunikasi) yang berhasil harus melibatkan etika, kesantunan berbahasa, dan budaya (antarbangsa, nasional, dan lokal).

Perencanaan dengan model pembelajaran CLIL, yakni (1) Memilih materi (isi materi) yang dimaksud, yakni materi mata pelajaran berdasarkan kurikulum, (2) Memilih topik (tema yang dipilih harus menarik) disesuaikan dengan kebutuhan siswa dan guru, dikaitkan dengan kehidupan nyata, melibatkan fungsi bahasa, dan model komunikasi serta mengintegrasikan budaya, (3) Mempertimbangkan komunikasi dan penggunaan bahasa dalam kegiatan pembelajaran menggunakan bahasa sebagai sarana komunikasi sebagaimana bahasa Indonesia digunakan untuk diskusi dan tugas presentasi materi pelajaran bahasa Indonesia, (4) Menyusun daftar kegiatan dalam pembelajaran (kegiatan pembelajaran harus menarik dan menggunakan konteks komunikasi nyata). Aktivitas seperti games, bercerita, lagu, rima, gambar, drama, bermain peran, 
dialog, dan presentasi dapat dengan mudah mengikutsertakan siswa dalam materi dan bahasa Indonesia, dan (5) Menyusun penilaian (penilaian harus menyeluruh) meliputi seluruh aspek pembelajaran yaitu kompetensi bahasa dan pengetahuan materi. Penilaian harus membantu siswa menunjukkan materi dan bahasa yang telah mereka pelajari. Penilaian dalam menulis cerpen dilakukan terhadap aspek relevansi isi dengan tema, struktur teks, pilihan kata (diksi), penggunaan kalimat (gaya bahasa), dan mekanik (ejaan dan tulisan tangan). Karakteristik CLIL adalah komponen 4C (Content, Cognition, Communication, and Culture). Keempat komponen tersebut dalam pembelajaran dijelaskan sebagai berikut (a) Content (isi materi). Content dalam hal ini adalah meningkatkan pengetahuan dan pemahaman materi. Penyampaian materi dilakukan guru saat menjelaskan materi maupun saat mengevaluasi hasil praktikum dan running dictation, (b) Communication (komunikasi). Communication dalam hal ini adalah meningkatkan keterampilan siswa menggunakan bahasa untuk berkomunikasi. Keterampilan berkomunikasi siswa diasah ketika berdiskusi hasil praktikum dan running dictation, (c) Cognition (Kognisi). Cognition dalam hai ini adalah mengembangkan keterampilan berpikir siswa. keterampilan berpikir siswa dikembangkan melalui kegiatan praktikum, diskusi kelompok, dan running dictation. Kegiatan praktikum meliputi ordering menulis data dan dividing membagi kelas ke dalam kelompok kecil, dan (d) Culture (kebudayaan). Culture dalam hal ini adalah meningkatkan pemahaman siswa terhadap diri sendiri dan orang lain sehingga munculkan sikap peduli dan tanggung jawab. Kegiatan ini dilakukan saat apersepsi yaitu guru memancing siswa dengan pertanyaan-pertanyaan tentang kehidupan mereka sehari-hari yang berkaitan dengan materi.

Berdasarkan permasalahan di atas maka perlu dilakukan penelitian tindakan kelas, untuk mendeskripsikan peningkatan kemampuan menulis cerpen dengan menggunakan model pembelajaran gabungan pendekatan pedagogi genre, saintifik, dan CLIL pada siswa kelas XI IPA-C SMAN 2 Kota Bengkulu Semester Ganjil 2018/2019.

\section{METODE}

Penelitian ini menggunakan metode deskriptif dan pendekatan kuantitatif serta prosedur Penelitian Tindakan Kelas (PTK) mencakup tahap perencanaan (plan), pelaksanaan (act), pengamatan (observe), dan refleksi (reflect) Penelitian ini menggunakan model Kemmis \& Taggart menekankan pada proses penemuan (Hopkin's, 1993:48). Pada tahap perencanaan dilakukan kegiatan menyusun Rencana Pelaksanaan Pembelajaran (RPP) menulis cerpen, menyiapan materi, menyusun pedoman pengamatan aktivitas siswa, dan menyiapkan media pembelajaran. Pada tahap pelaksanaan tindakan, mencakup pendahuluan, inti, dan penutup menggunakan model tiga pendekatan. Pada tahap observasi dilakukan pengamatan pada perubahan aktivitas siswa dalam proses dan hasil pembelajaran menulis cerpen. Pada tahap refleksi, guru mendeskripsikan semua proses yang sudah dan belum dilakukan sebagai upaya perbaikan terhadap permasalahan yang belum dapat diselesaikan. Data penelitian berupa teks cerpen tulisan siswa kelas XI IPA-C SMAN 2 Kota Bengkulu sebanyak 28 orang. Penelitian dilakukan pada semester ganjil tahun 2018/2019 yakni pada bulan Agustus dan September 2018. Pengumpulan data menggunakan teknik tes dan pengamatan. Alat pengumpul data yang digunakan 
berupa (1) pedoman tes menulis cerpen yang didasarkan pada beberapa aspek, meliputi isi, struktur, diksi, penggunaan kalimat dan gaya bahasa, dan mekanik, (2) pedoman pengamatan aktivitas siswa mencakup aspek disiplin, tanggung jawab, kerjasama, kemandirian. Analisis data hasil kemampuan menulis cerpen menggunakan rumus rerata dan secara rentang penilaian kualitatif untuk menentukan aktivitas siswa dalam proses pembelajaran bahasa Indonesia. Patokan Indikator keberhasilan, bahwa siswa dinyatakan berhasil apabila mencapai nilai secara individual minimal 75 dan secara klasikal jika sebanyak $80 \%$ siswa mencapai nilai sebesar 75. Aktivitas siswa dinyatakan meningkat jika aspek disiplin, tanggung jawab, kemandirian, dan kerjasama mengalami perubahan dari tidak aktif menjadi aktif atau sangat aktif.

\section{HASIL DAN PEMBAHASAN}

\section{Hasil Penelitian}

Hasil penelitian Peningkatan Kemampuan Menulis Cerpen menggunakan model pembelajaran tiga pendekatan pedagogi genre, saintifik, dan CLIL pada siswa kelas XI IPA-C SMAN 2 Kota Bengkulu Semester Ganjil Tahun 2018/2019 pada 28 orang dilaksanakan dalam dua siklus sebagai berikut ini.

a. Hasil Pembelajaran Siklus I

Pembelajaran siklus 1 dilakukan dalam empat tahapan, yakni (1) Tahap Perencanaan, dilakukan persiapan pembelajaran mencakup (1) penyusunan Rencana Pelaksanaan Pembelajaran (RPP) materi pembelajaran menulis teks cerpen. Pembelajaran menulis cerpen menggunakan model pembelajaran tiga pendekatan dilakukan 3 kali pertemuan dengan materi (a) komponen menulis cerpen, (b) menemukan nilai-nilai kehidupan dalam cerpen Sulaiman pergi ke Tanjung China, (c) menentukan struktur teks cerpen dan unsur pembangun cerpen Sulaiman pergi ke Tanjung China dan satu kali pertemuan (d) menyusun kerangka dan produksi teks cerpen dengan tema kasih sayang, (2) menyusun materi pembelajaran, (3) menyusun lembar kerja siswa, (4) menyusun media pembelajaran dan alat peraga, (5) menyusun pedoman pengamatan aktivitas siswa, dan (6) menyusun pedoman penilaian menilis cerpen siswa, (2) Tahap pelaksanaan, dilakukan proses pembelajaran sesuai perangkat pembelajaran yang telah dirancang melalup proses pelaksanaan pembelajaran dengan tahapan (a) pendahuluan, (b) inti pembelajaran, dan (c) penutup, (3) Tahap Pengamatan, dilakukan melalui kolaborasi bersama dosen dan guru. Mengamati proses pembelajaran yang dilakukan siswa, yakni guru mengamati aktivitas siswa. Hasil proses pembelajaran bahwa secara umum siswa cukup aktif dalam pembelajaran dalam hal disiplin, tanggung jawab, kerjasama, dan kemandirian dalam pembelajaran menulis cerpen, dan (4) Tahap Refleksi, bahwa pada akhir kegiatan pembelajaran siklus 1 dapat dideskripsikan bahwa proses pembelajaran sudah dapat terlaksana dengan baik tetapi belum mencapa indikator keberhasilan sehingga pembelajaran dilanjutkan pada siklus II dengan menyiapkan beberapa materi dan rencana secara lebih baik.

Dari hasil pembelajaran kemampuan menulis cerpen siswa pada siklus I dapat dideskripsikan sebagaimana tabel berikut ini.

Tabel 1. Hasil Kemampuan Menulis Cerpen Siklus 1

\begin{tabular}{|c|l|c|l|}
\hline No. & \multicolumn{1}{|c|}{ Aspek (Skor) } & Rerata & Kategori \\
\hline 1 & Isi (25) & 17,5 & Baik \\
\hline 2 & Struktur (20) & 14,7 & Baik \\
\hline 3 & Diksi (20) & 14,5 & Baik \\
\hline 4 & $\begin{array}{l}\text { Kalimat Gaya } \\
\text { Bahasa (25) }\end{array}$ & 16,7 & Baik \\
\hline 5 & Mekanik (10) & 6,8 & Cukup \\
\hline & $\begin{array}{l}\text { Kemampuan } \\
\text { Menulis Cerpen }\end{array}$ & 70,2 & Baik \\
\hline
\end{tabular}


Dari tabel di atas dapat diketahui bahwa hasil pembelajaran kemampuan menulis cerpen siswa pada siklus I berkategori baik dengan rerata nilai sebesar 70,2 . Hal ini menunjukkan bahwa kemampuan menulis cerpen siswa masih perlu ditingkatkan proses dan hasil pembelajarannya. Berdasarkan tiap-tiap aspek kemampuan menulis cerpen diperoleh bahwa (1) aspek isi berkategori baik dengan nilai rata-rata sebesar 17,5, (2) aspek struktur teks berkategori baik dengan rerata sebesar 14,5 , (3) aspek diksi berkategori baik dengan rerata sebesar 14,5 , (4) aspek kalimat gaya bahasa berkategori baik dengan rerata sebesar 16,7, dan aspek mekanik berkategori cukup dengan rerata sebesar 6,8 dan masih perlu ditingkatkan.

b. Hasil Pembelajaran Siklus II

Pembelajaran siklus 1 dilakukan dalam empat tahapan, yakni (1) Tahap Perencanaan, dilakukan persiapan pembelajaran mencakup (1) penyusunan Rencana Pelaksanaan Pembelajaran (RPP) materi pembelajaran menulis teks cerpen. Pembelajaran menulis cerpen menggunakan model pembelajaran tiga pendekatan dilakukan 3 kali pertemuan dengan materi (a) menentukan aspek bahasa dan struktur teks cerpen "Penantian panjang resonansi Jiwa", (b) menemukan nilai-nilai kehidupan, struktur teks, dan unsur pembangun cerpen 'Robohnya Surau Kami', (c) menentukan aspek menulis cerpen 'Robohnya Surau Kami', dan satu kali pertemuan (d) menyusun kerangka dan produksi teks cerpen dengan tema kasih sayang, (2) menyusun materi pembelajaran, (3) menyusun lembar kerja siswa, (4) menyusun media pembelajaran dan alat peraga, (5) menyusun pedoman pengamatan aktivitas siswa, dan (6) menyusun pedoman penilaian menilis cerpen siswa, (2) Tahap pelaksanaan, dilakukan proses pembelajaran sesuai perangkat pembelajaran yang telah dirancang melalup proses pelaksanaan pembelajaran dengan tahapan (a) pendahuluan, (b) inti pembelajaran, dan (c) penutup, (3) Tahap Pengamatan, dilakukan melalui kolaborasi bersama dosen dan guru. Mengamati proses pembelajaran yang dilakukan siswa, yakni guru mengamati aktivitas siswa. Hasil proses pembelajaran bahwa secara umum siswa sudah sangat aktif dalam pembelajaran dalam hal disiplin, tanggung jawab, kerjasama, dan kemandirian dalam pembelajaran menulis cerpen baik dalam kelompok maupun secara klasikal, dan (4) Tahap Refleksi, bahwa pada akhir kegiatan pembelajaran siklus II dapat dideskripsikan bahwa proses pembelajaran sudah dapat terlaksana dengan baik dan mencapa indikator keberhasilan sehingga kegiatan pembelajaran PTK diakhiri.

Dari hasil pembelajaran kemampuan menulis cerpen siswa pada siklus II dapat dideskripsikan sebagaimana tabel berikut ini.

Tabel 2. Hasil Kemampuan Menulis Cerpen Siklus 2

\begin{tabular}{|c|l|c|l|}
\hline No. & \multicolumn{1}{|c|}{ Aspek (Skor) } & Rerata & Kategori \\
\hline 1 & Isi (25) & 19,96 & Baik \\
\hline 2 & Struktur (20) & 16,93 & $\begin{array}{l}\text { Sangat } \\
\text { Baik }\end{array}$ \\
\hline 3 & Diksi (20) & 16,93 & $\begin{array}{l}\text { Sangat } \\
\text { Baik }\end{array}$ \\
\hline 4 & $\begin{array}{l}\text { Kalimat Gaya Bahasa } \\
\text { (25) }\end{array}$ & 18,75 & Baik \\
\hline 5 & Mekanik (10) & 7,57 & Baik \\
\hline & $\begin{array}{l}\text { Kemampuan Menulis } \\
\text { Cerpen }\end{array}$ & 80,14 & $\begin{array}{l}\text { Sangat } \\
\text { Baik }\end{array}$ \\
\hline
\end{tabular}

Dari tabel di atas dapat diketahui bahwa hasil pembelajaran kemampuan menulis cerpen siswa pada siklus II berkategori sangat baik dengan rerata sebesar 80,14. Hal ini menunjukkan bahwa kemampuan menulis cerpen siswa telah meningkat dari 
pembelajaran siklus sebelumnya dan perlu terus dipertahankan hasil pembelajarannya. Berdasarkan tiap-tiap aspek kemampuan menulis cerpen diperoleh bahwa (1) aspek isi berkategori baik dengan nilai rerata sebesar 19,96, (2) aspek struktur teks berkategori sangat baik dengan rerata sebesar 16,93, (3) aspek diksi berkategori sangat baik dengan rerata sebesar 16,93, (4) aspek kalimat gaya bahasa berkategori baik dengan rerata sebesar 18,75, dan aspek mekanik berkategori baik dengan rerata sebesar 7,57 dan masih perlu ditingkatkan.

\section{Pembahasan}

Berdasarkan hasil penelitian diperoleh bahwa terjadi peningkatan kemampuan menulis Cerpen dengan menggunakan model pembelajaran gabungan tiga pendekatan pedagogi genre, saintifik, dan CLIL pada siswa kelas XI IPA-C SMAN 2 Kota Bengkulu. Peningkatan ini dapat dilihat dari hasil pembelajaran menulis cerpen pada 28 orang siswa pada siklus I berkategori baik dengan rerata nilai sebesar 70,2 meningkat pada siklus II berkategori sangat baik dengan rerata nilai sebesar 80,14 . Hal ini sesuai dengan pendapat Wiratno (2014) bahwa menulis cerpen merupakan tuntutan yang harus dicapai siswa dalam pembelajaran bahasa Indonesia pada berbagai tingkatan pendidikan baik di SMP maupun SMA. Pembelajaran menulis cerpen yang berkualitas harus didasarkan pada berbagai komponen penilaian analitik mencakup relevansi isi, struktur, diksi, kalimat gaya bahasa, dan mekanik.

Berdasarkan data hasil penilaian kemampuan menulis cerpen menurut aspek/komponen dapat dideskripsikan bahwa aspek mekanik yakni ejaan dan tulisan tangan masih berkategori cukup pada siklus I. Hal ini terlihat dari tulisan cerpen yang dibuat siswa masih belum memperhatikan ejaan, seperti penulisan kata depan 'di' masih dirangkai dengan kata yang mengikuti. Misalnya disekolah, diluar, dirumah, dan disana, yang seharusnya ditulis di rumah, di sekolah, di sana, dan di luar. Penggunaan tanda baca /ke 1, ke 2/, seharusnya ditulis /ke-1, ke-2/. Penulisan kata baku dan istilah serapan yang masih terpengaruh bahasa daerah atau belum benar terjadi pada penggunaan kata seperti sebua, disebua, cewe, telpon, dan cuma yang seharusnya ditulis sebuah, disebuah, cewek, telepon, dan hanya. Disamping itu, terdapat kesalahan dalam menggunakan kata pada awal kalimat seperti kata /dan/ yang digunakan untuk mengawali sebuah kalimat. Penggunaan tanda baca /,/ (koma) pada kata transisi yang mengawali kalimat sebagai penghubung antarkalimat juga masih terjadi, seperti kata //...kemudian.../ seharunya difungsikan di awal kalimat seperti "Kemudian, .." Permasalahan aspek mekanik ini pada siklus II sudah berkurang tingkat kesalahan penggunaannya.

Hasil ini masih perlu terus ditingkatkan dengan melakukan latihan menulis secara terus menerus dengan memperhatikan organisasi tulisan yang baik. Hal ini sebagaimana ditegaskan oleh MaCrimmon (1984:10-11) bahwa menulis perlu dilakukan perencanaan menulis, produk tulisan, dan mereviuw tulisan agar tulisan cerpen yang dibuat mudah dipahami pembaca. Disamping itu, sebuah cerpen harus ditulis dengan memperhatikan unsur pembangun cerpen sebagaimana ditegaskan oleh Garry (2011:44). Menurutnya, bahwa pembelajaran cerpen harus memperhatikan struktur intrinsik cerpen, yang mencakup tema dan amanat, alur, tokoh dan penokohan, latar, sudut padang, dan gaya penulisan cerita.

Model pembelajaran gabungan tiga pendekatan yang disyaratkan kurikulum 2013 dalam pembelajaran bahasa Indonesia mampu mengantarkan siswa menulis cerpen secara cermat dan sistematis karena dari unsur CLIL bahwa pembelajaran bahasa dari segi isi materi bahasa dipelajari 
sekaligus menggunakan bahasa Indonesia. Menurut Coyle (2008) pembelajaran ini sangat tepat karena belajar berbahasa dalam hal ini bahasa Indonesia dengan menggunakan alat komunikasi dalam bahasa Indonesia tersebut. Disisi lain, pembelajaran disajikan dengan tahapan menganalisis konteks dan pemodelan serta mengonstruksi teks secara bersama dan secara mandiri melalui langkah-langkah pembelajaran ilmiah (saintifik) sehingga mampu mewujudkan produk teks cerpen.

\section{PENUTUP}

\section{Kesimpulan}

Berdasarkan hasil penelitian dan pembahasan dapat disimpulkan bahwa terjadi peningkatan kemampuan menulis cerpen dengan menggunakan model pembelajaran tiga pendekatan pedagogi genre, saintifik, dan CLIL pada siswa kelas XI IPA-C SMAN 2 Kota Bengkulu dalam proses dan hasil pembelajaran. Hal ini dapat Hal ini terbukti dari hasil pembelajaran pada siklus I diperoleh rerata sebesar 70,21 dengan kategori baik dan meningkat pada hasil pembelajaran siklus II dengan rerata sebesar 80,14 dengan kategori sangat baik. Aktivitas siswa mencakup aspek disiplin, bertanggung jawab, kerjasama dan mandiri dengan kategori aktif pada siklus I meningkat menjadi sangat aktif pada siklus II dalam materi pembelajaran mendeskripsikan struktur teks, nilai-nilai kehidupan, dan struktur pembangun cerpen yang dipelajari.

\section{Saran}

Berdasarkan kesimpulan penelitian dikemukakan beberapa saran, yakni (1) dalam pembelajaran menulis cerpen yang berkualitas guru diharapkan menggunakan model pembelajaran tiga pendekatan yakni pedagogi genre, saintifik, dan CLIL secara kreatif agar dapat memfasilitasi siswa dalam belajar secara mandiri, bertanggung jawab, dan disiplin serta bekerjasama dan (2) siswa lebih banyak beraktivitas melalui berlatih secara rutin agar hasil menulisnya lebih baik lagi.

\section{Daftar Pustaka}

Abrams, M.H. 1999. A Glossary of Literary Terms, Seventh Edition. USA: Thomson Learning.

Bachman, Lyle F. 1990. Fundamental Considerations in Language Testing. Oxford: Oxford University Press.

Coyle, Do. 2008. Content and Language Integrated Learning; Motivating Learners and Teachers. $\mathrm{Http}: / /$ blocs.xtec.cat/clilpractiques1/fi les/2008/11/slrcoyle.pdf. Diakses tanggal 10 April 2012.

Disher, Garry. 2011. Writing Fiction, An Introduction To The Craft. Australia: Allen\&Unwin.

Djiwandono, Soenardi. 2008. Tes Bahasa Pegangan Bagi Pengajar Bahasa. Jakarta: PT Indeks.

Hadley, Alice Omaggio. 1993. Teaching Language in Context. Boston: Heinle \& Heinle Publishers.

Heaton, J.B. 1988. Writing English Language Tests. New York: Longman Group UK Limited.

Hopkins, David. 1993. A Teacher's Guide to Classroom Research. Philadelphia: Open University Press.

Ideris, Haderi. 2013. Pintar Menulis Cerpen: Cara Jitu Mendobrak Pintu Kesulitan Menulis. Banjarmasin: Dreammedia.

Jacobs, Holly L., et.al. 1981. Testing ESL Composition: A. Practical Approach. Massacheserttes: Newbury House Publishers, Inc.

Johnson, Elaine B. 2002. Contextual Teaching and Learning: What it is and why it's here to stay. Callifornia: Corwin Press, Inc.

Kementerian Pendidikan dan Kebudayaan RI. 2013. Bahasa Indonesia: Wahana 
Pengetahuan untuk SMP/MTs Kelas VII. Buku Siswa. Jakarta: Kementerian Pendidikan dan Kebudayaan.

Kementerian Pendidikan dan Kebudayaan RI. 2014. Buku Guru: Bahasa Indonesia Wahana Pengetahuan untuk SMP/MTs Kelas VII. Jakarta: Kementerian Pendidikan dan Kebudayaan.

Latief, Muh. Adnan. 2002. "Pengembangan Bahan Ajar Kontekstual Bahasa Inggris SLTP Cawu 2 Untuk 6 Provinsi di Kalimantan dan Sulawesi", Jurnal Penelitian Kependidikan, Tahun 12 Nomor 1, Juni.

McCrimmon, James M. 1984. Writing with a Purpose. USA: Houghton Mifflin Company.

Murray, Rowenna \& Sarah Moore. 2009.

The Handbook of Academic Writing, A Fresh Approach. New York: Mc-Graw Hill.

Nur, Muhammad. 2001. "Pengajaran dan Pembelajaran Kontekstual", Makalah Pelatihan TOT Guru Mata Pelajaran SLTP dan MTs, Juni.

Richards, Jack C. dan Willy A. Renandya. 2002. Methodology in Language Teaching,An Anthology of Current Practice. USA: Cambridge University Press.
Setyaningrum, Wahyu. 2010. Content and Language Integrated Learning (CLIL) sebagai Alternatif Pendekatan dalam Pembelajaran Matematika Berbahasa Inggris.

http://staff.uny.ac.id/sites/default/fil es/penelitian/Wahyu/Setyaningrum, M.Ed./CLIL/semnas.pdf. Diakses tanggal 10 April 2012.

Sevilla, Consuelo G, dkk. 1993. Pengantar Metode Penelitian. Terjemahan Alimuddin Tuwu. Jakarta: UI Press.

Satori. 2013. "Komponen Kompetensi Profesional Guru", Pendidikanku: Informasi Pendidikan Terkini. Http://sdnwonoue.blogspot.com/201 3/08.html. Diunduh, 27 April 2015.

Wiratno, Tri. 2014. "Pembelajaran Bahasa Indonesia berbasis Teks dalam Kurikulum 2013". Materi Pelatihan Instruktur Nasional Pembelajaran Bahasa Indonesia Berbasis Teks. Jakarta: Badan Pengembangan dan Pembinaan Bahasa.

Yulistio, Didi. 2012. "Pengaruh Strategi Pembelajaran dan Kemampuan Penalaran Terhadap Keterampilan Menulis", Disertasi Tidak Diterbitkan. Jakarta: UNJ.

Zainurrahman. 2011 Menulis: Dari Teori Hingga Praktik (Penawar Racun Plagiarimse). Bandung: Alfabeta. 